\title{
Percepatan pendapatan petani sawit melalui peningkatan kinerja pemasaran dan strategi bersaing
}

\section{Enni Savitri*, \& Riska Natariasari}

\author{
Fakultas Ekonomi dan Bisnis, Universitas Riau \\ *enni.savitri@lecturer.unri.ac.id
}

\begin{abstract}
The oil palm business is one of the businesses that can help the country's economy and help improve people's welfare. The effectiveness of SME business performance is influenced by training, organizing, utilization, and development. The target community is SMEs in Lebuh Lurus village, Inuman Kuantan Singingi sub-district. Increased marketing performance and competitive strategies can be applied to oil palm farmers with training and skill mentoring. This activity is carried out by direct counseling/discussion, discussion, and question and answer. The implementation of this activity is divided into several stages, including preparation, counseling and assistance, evaluation, and discussion. Competitive advantage, competitive intelligence, cross-functional working relationships as solutions to improving marketing performance in oil palm plantation SMEs in the province of Riau. The results of this activity teaches and administers to the oil palm smallholders in implementing competitive strategies and marketing palm oil products. Training for human resource oil palm workers and the creation of agricultural counseling programs.
\end{abstract}

\begin{abstract}
Abstrak Bisnis kelapa sawit merupakan salah satu bisnis yang dapat membantu perekonomian negara dan membantu meningkatkan kesejahteraan masyarakat. Efektivitas kinerja usaha Usaha Kecil dan Menengah (UKM) dipengaruhi oleh pembinaan, pengaturan, pendayagunaan dan pengembangan. Masyarakat sasaran adalah UKM di desa Lebuh Lurus Kecamatan Inuman Kabupaten Kuantan Singingi. Peningkatan kinerja pemasaran dan strategi bersaing yang bisa diterapkan pada petani sawit dengan pelatihan dan pendampingan keterampilan. Kegiatan ini dilakukan dengan penyuluhan/diskusi langsung, diskusi dan tanya jawab. Pelaksanaan kegiatan ini dibagi dalam beberapa tahap, diantaranya: persiapan, penyuluhan dan pendampingan, evaluasi dan diskusi. Keunggulan bersaing, inteligen pesaing, hubungan kerja lintas fungsi sebagai solusi untuk meningkatkan kinerja pemasaran pada UKM perkebunan kelapa sawit di Provinsi Riau. Hasil kegiatan ini mengajarkan dan mendampingi para pelaku UMK petani sawit dalam menerapkan strategi bersaing, pemasaran produk kelapa sawit. Pelatihan bagi sumber daya manusia (SDM) pekerja kelapa sawit dan terciptanya program penyuluhan pertanian.
\end{abstract}

Keywords: competitive strategy; marketing performance; training; mentoring

\section{OOPEN ACCESS}

Citation: Savitri, E., \& R. Natariasari. (2021). Percepatan pendapatan petani sawit melalui peningkatan kinerja pemasaran dan strategi bersaing. Riau Journal of Empowerment, 4(1), 41-47. https://doi.org/10.31258/raje.4.1.41-47

Received: 21-01-21 Revised: 2021-04-19 Accepted: 2021-04-21

Language: Bahasa Indonesia (id)

ISSN 2623-1549 (online), 2654-4520 (print)

C2021 Enni Savitri, \& Riska Natariasari. Author(s) retain the copyright of article published in this journal, with first publication rights granted to Riau Journal of Empowerment. The article is licenced under Creative Commons Attribution 4.0 International License. This license permits unrestricted use, distribution, and reproduction in any medium, provided the original author and source are credited. 


\section{PENDAHULUAN}

Munculnya persaingan dalam dunia bisnis merupakan hal yang tidak dapat dihindari. Dengan adanya persaingan, maka para petani sawit yang tergabung dalam UKM dihadapkan pada berbagai peluang dan ancaman baik yang berasal dari luar maupun dari dalam negeri. Untuk itu setiap UKM dituntut untuk selalu mengerti dan memahami apa yang terjadi dipasar dan apa yang menjadi keinginan konsumen, serta berbagai perubahan yang ada di lingkungan bisnisnya, sehingga mampu bersaing dengan lainnya (Weerawardena, 2003). Sudah seharusnya UKM berupaya untuk meminimalisasi kelemahan-kelemahannya dan memaksimalkan kekuatan yang dimilikinya. Dengan demikian UKM dituntut untuk memilih dan menetapkan strategi yang dapat digunakan untuk menghadapi persaingan.

Dengan adanya tekanan persaingan begitu ketat, sehingga secara langsung atau tidak langsung sangat memengaruhi kinerja UKM yang para anggotanya adalah petani sawit skala kecil dan menengah. Perubahan yang begitu cepat dewasa ini, baik dalam hal teknologi, kebutuhan pelanggan dan penawaran harga tandan sawit semakin pendek menyebabkan permasalahan serius bagi para petani sawit yang tergabung dalam koperasi tani sawit yang terdiri dari beberapa UKM. Keberadaan pemerintah dalam hal peningkatan kinerja usaha kecil dan menengah sudah sangat serius ini terbukti dari pemberian kredit lunak kepada pemilik usaha untuk dapat meningkatkan kapabilitas mereka dalam meningkatkan kinerja perusahaan, namun pemberian kredit oleh pemerintah masih kurang merata, karena banyaknya usaha kecil dan menengah yang ada di Indonesia. Kecenderungan pemberian kredit adalah pada pengusaha besar daripada pengusaha kecil dan menengah karena alasan kelemahan manajerial pemasaran.

Sebagian UKM masih mempunyai berbagai kelemahan yang bersifat eksternal, seperti kurangnya kemampuan untuk beradaptasi terhadap pengaruh lingkungan yang strategis, kurang cekatan dalam peluang-peluang usaha, kurangnya kreativitas dan inovasi dalam mengantisipasi berbagai tantangan sebagai akibat resesi ekonomi yang berkepanjangan. Disamping itu faktor internal dari sebagian UKM yaitu kurangnya kemampuan manajerial dan keterampilan, kurangnya akses terhadap informasi teknologi, permodalan dan pasar. Kelemahan internal ini disebabkan sebagian SDM pengelola UKM kurang berkualitas dalam mengantisipasi berbagai masalah yang sedang dihadapi.

Dari berbagai kekurangan yang tersebut diatas diperlukan adanya perhatian khusus terhadap nasib dari keberadaan UKM sebagai penunjang ekonomi riil masyarakat. Persaingan usaha yang begitu ketat mengharuskan perusahaan memiliki keunggulan bersaing, jika tidak maka UKM tersebut tidak dapat bertahan lama. Keunggulan bersaing dalam sebuah UKM dapat diperoleh dengan memperhatikan nilai superior bagi pelanggan, kebudayaan dan iklim untuk efisiensi dan efektivitas. Agar menang dalam suatu persaingan, maka dalam memasarkan produk minyak sawit saat ini produsen tidak hanya berdasarkan pada kualitas produk saja, tetapi juga bergantung pada strategi yang umumnya digunakan perusahaan yaitu orientasi pasar (Alimuddin, 2016) dan inovasi (Anshori, 2015) serta orientasi kewirausahaan (Hartanty \& Aliyah, 2013).

Perubahan harga sawit akhir-akhir ini yang terjadi dalam industri sawit menyebabkan rendahnya pendapatan para petani sawit diantaranya adalah menurunnya nilai penjualan. Kasus tersebut akan dijadikan penerapan penelitian ini. Persaingan diantara para UKM memasarkan produk sawitnya ke beberapa perusahaan yang ada disekitar Kuantan Singingi yang ada semakin menguat dan berbagai cara yang dilakukan oleh UKM untuk meningkatkan 
kinerja pemasarannya. Dari kasus yang terjadi pada UKM yang ada di Desa Lebuh lurus, terlihat bahwa keunggulan bersaing para petani sawit untuk mendapatkan harga yang pantas bagi hasil sawitnya menarik memberikan kontribusi bagi para petani sawit. Perkembangan UKM di Desa Lebuh lurus berjalan lambat karena hanya ditemukan sedikit UKM di desa tersebut. Oleh karena itu, kegiatan pengabdian ini diharapkan dapat menumbuhkan jiwa kewirausahaan pada warga/masyarakat Desa Lebuh Lurus serta membekali para pemilik UKM dengan pentingnya strategi bersaing dalam mendapatkan harga yang wajar dan bersaing serta menigkatkan kinerja pemasaran sawit produk Desa Lebuh Lurus.

\section{METODE PENERAPAN}

Kegiatan ini dilakukan dengan penyuluhan/diskusi langsung, diskusi dan tanya jawab. Pelaksanaan kegiatan ini dibagi dalam beberapa tahap, diantaranya:

1. Para petani sawit yang tergabung dalam UKM perlu mendapatkan penjelasan melalui pelatihan tentang kinerja pemasaran, yaitu menyangkut strategi pemasaran dengan penekanan pada materi produk, kemasan, promosi penetapan harga dan sebagainya.

2. Pembuatan materi penyuluhan tentang pentingnya kinerja pemasaran UKM, supaya hasil kelapa sawit mudah dipasarkan ke konsumen.

3. Pembuatan materi pendukung lainnya berupa pamlet dan buku saku yang dapat menambah pengetahuan petani sawit, sehingga tercipta sinergi diantara para petani sawit (Syahza, 2019)

4. Diskusi dengan UKM tentang strategi yang harus dilaksanakan untuk bisa memasarkan hasil panen kelapa sawit supaya ada kenaikan penjualan setiap panen.

\section{Tahap penyuluhan dan pendampingan}

Pada tahap ini diajarkan strategi pemasaran yang perlu dilakukan tentang pengambilan keputusan-keputusan tentang biaya pemasaran, bauran pemasaran, alokasi pemasaran dalam hubungan dengan keadaan lingkungan yang diharapkan dan kondisi persaingan. Kualitas produk sawit (aspect product) menjadi muara awal bagi penentuan harga, tempat dan promosi (price, place, promotion). Selama petani masih mempertahankan kualitas produk, pemasaran dengan mengandalkan jaringan dengan tauke (promotion) di pasar tradisional (place) maka petani akan senantiasa memperoleh keuntungan yang memuaskan. Perubahan dan perbaikan dalam usaha tani sawit membuat petani menyadari pentingnya melakukan perubahan strategi pemasaran produk kelapa sawit yang sesuai dengan tuntutan pasar. Pada tahap pendampingan, Petani maupun kelompok tani harus mengadakan segmentasi, targeting dan positioning ulang dengan pola pemasaran yang selama ini berjalan. penjelasan tentang pentingnya strategi pemasaran untuk pemasaran produk Konsep ini akan berkaitan dengan pola bauran pemasaran yang meliputi aspek produk, harga, promosi, dan tempat. Aspek bauran pemasaran tersebut dapat diperkuat melalui perbaikan pada aspek produk, kelembagaan, serta regulasi untuk meningkatkan keberpihakan pasar terhadap produk kelapa sawit petani.

\section{Tahap evaluasi}

Pada tahap ini evaluasi atas sasaran dan manfaat utamanya adalah diterapkannya strategi bersaing dan strategi pemasaran yang menggunakan pendekatan terpadu dan dirancang sedemikian rupa dengan sasaran utama memperbaiki serta meningkatkan kinerja usaha UKM serta kehidupan sosial ekonomi pelaku dan pemilik UKM (Savitri \& Syahza, 2019). Evaluasi ini dengan melihat adanya kenaikan pendapatan petani sawit pada setiap kali panen, 
peningkatan volume penjualan dan distribusi penyebaran daerah pemasaran hasil panen sawit. Peningkatan wawasan, sikap, maupun pengembangan masyarakat perkebunan yang meliputi aspek kemandirian, kreativitas dan pertumbuhan kelembagaan sosial, ekonomi serta pemerintahan pedesaan. Pembangunan sumber daya petani ini berarti pembangunan unsur sosial. Pembangunan tata hubungan antar sistem secara harmonis yang meliputi unsur fisik, sosial dan lingkungan sehingga program dapat mencapai tujuan.

\section{HASIL DAN KETERCAPAIAN SASARAN}

Strategi bersaing yang tepat untuk diterapkan bagi petani sawit adalah menggunakan konsep daya saing. Keunggulan saat ini bisa saja menjadi ketidakunggulan di masa yang akan datang atau sesuatu yang belum unggul saaat ini sangat mungkin untuk semakin tidak unggul lagi dimasa yang akan datang (Parham, 2011). Kemampuan suatu daerah untuk meningkatkan daya saing perekonomiaannya akan sangat bergantung pada kemampuan daerah dalam menentukan faktor-faktor yang dapat digunakan sebagai ukuran daya saing daerah dan kemampuan daerah dalam menetapkan kebijakan terhadap daerah lain.

Konsep rantai nilai adalah pendekatan terpadu berorientasi proses untuk menyediakan, memproduksi, mengirim produk serta jasa kepada konsumen (Pujawan dan Mahendrawati, 2010). Dengan demikian diperlukan pula sebuah sistem terpadu yang bertugas dalam pengumpulan, pengolahan, penyimpanan, dan penyebarluasan informasi kepada setiap mitra usaha tersebut. Muchlis et al., (2012) menyatakan bahwa komitmen dan kepercayaan adalah dua aspek dominan yang mendasari munculnya kerja sama, daya saing serta jaminan keuntungan finansial. faktor keuangan pada pembiayaan pasokan Tandan Buah Sawit (TBS) yang melibatkan kelompok tani dan sangat menentukan kinerja rantai pasokan TBS dan daya saing kelapa sawit (Solikhin et al., 2012).

Cara yang tepat dilakukan dalam meningkatkan kinerja pemasaran produk kelapa sawit adalah peningkatan volume penjualan, luas daerah pemasaran dan pangsa pasar. Untuk meningkatkan kinerja pemasaran pada UKM perkebunan kelapa sawit di Provinsi Riau perlu dilakukan peningkatan keunggulan bersang dengan cara meningkatkan intelijen pesaing dan hubungan kerja lintas fungsi. Upaya peningkatan kinerja pemasaran secara prioritas untuk meningkatkan keunggulan bersaing dan kinerja pemasaran pada perusahaan perkebunan kelapa sawit di Provinsi Riau perlu dilakukan hal-hal sebagai berikut: meningkatkan komunikasi. Komunikasi (Comunication) adalah kebebasan dan keterbukaan melakukan pertukaran ide dan informasi diantara para pelaku UKM untuk memperjelas tujuan (Hutt dan Speh, 2004). Komunikasi yang efektif dirancang dengan mempertimbangkan kriteria yaitu kepada siapa komunikasi dilakukan, apa yang akan dikomunikasikan, bagaimana cara mengkomunikasikannya dan dimana komunikasi itu disampaikan. Melakukan survei pelanggan. Survei pelanggan berguna untuk merancang strategi pemosisian (position strategy) dan hasil evaluasi strategi (Cravens dan Piercy, 2006). Survei pelanggan pada dasarnya dilakukan untuk menganalisa pelanggan berkaitan dengan pembentukan segmen pasar sehingga dapat diketahui pelanggan dalam setiap segmen. Melakukan wawancara dengan pemasok. Pemasok merupakan pihak yang menawarkan input kepada perusahaan untuk menunjang proses produksi. Meningkatkan responsivitas para pelaku UKM. Mengevaluasi Produk Pesaing. Produk pesaing adalah segala sesuatu yang ditawarkan kepasar oleh pesaing untuk memuaskan kebutuhan pelanggan. Dalam kaitan ini, sesuatu yang ditawarkan itu adalah produk kelapa sawit baik berupa TBS, CPO atau PKO. Menyediakan basis data pesaing. Basis data (database) merupakan salah satu bentuk sistem informasi manajemen (SIM) yang 
menyediakan data mentah bagi para pengambil keputusan. Melakukan Aliansi Strategik dengan Pesaing. Keberhasilan aliansi sangat berguna pada perpaduan kemampuan efektif organisasi yang berpartisipasi pada pencapaian komitmen penuh setiap pihak yang bermitra. Pelatihan SDM pelaku UKM terlihat pada gambar 1.

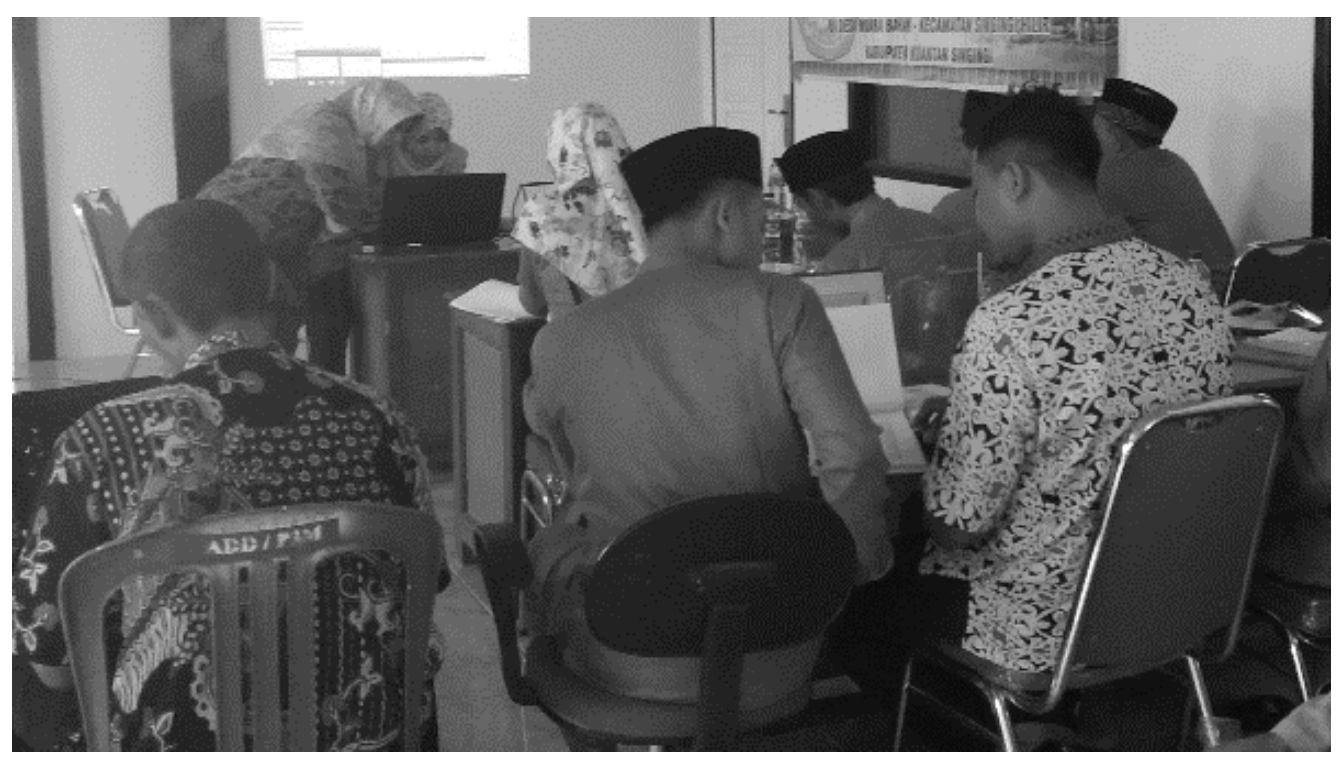

Savitri \&

Natariasari

Gambar 1. Pelatihan Pelaku UKM

Peningkatan Kemampuan SDM pekerja kelapa sawit. Pengukuran produktivitas tenaga kerja dilapangan perlu dilakukan guna mengetahui tolak ukur produktivitas kerja perlu diketahui sebab menentukan bentuk kebijakan yang dapat dilakukan UKM. Pengelolaan tenaga kerja yang baik dapat mengurangi tingkat kesalahan tenaga kerja panen kelapa sawit dan meningkatkan produktivitas kerja sehingga kualitas kelapa sawit yang dihasilkan menjadi baik dan memudahkan pencapaian tujuan perusahaan. Manajemen tenaga kerja pada perusahaan perlu ditingkatkan dengan memberdayakan SDM unggul dan pengelolaan yang baik. Manajemen tenaga kerja yang baik adalah manajemen yang menciptakan keharmonisan diantara pekerja panen, pekerja pengangkutan Tandan Buah Segar dan buah lepas serta pekerja pengolahan hasil kelapa sawit (Hasibuan, 2009). Pendampingan terlihat pada Gambar 2.

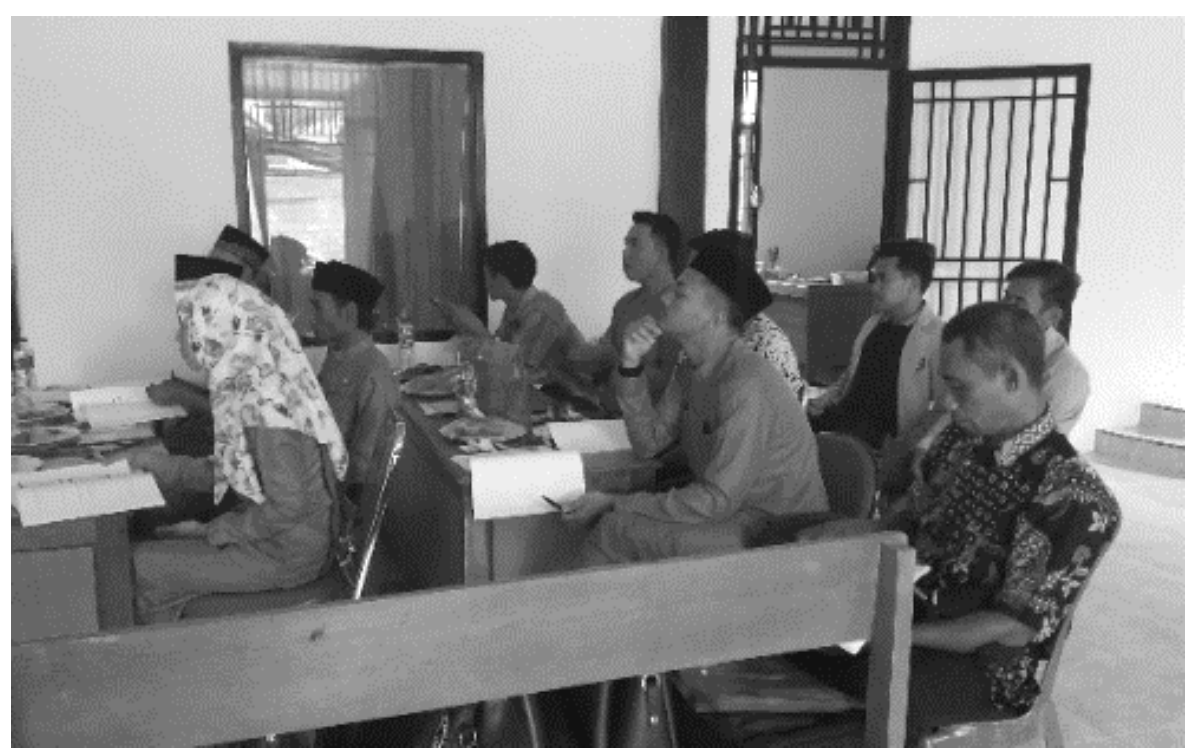

Gambar 2. Pendampingan pelaku UKM petani sawit 
Pelatihan dan Keterampilan serta keahlian yang akan dibekali pada UKM petani sawit yaitu; Peran penyuluh pertanian dalam melaksanakan edukasi. Menurut Mardikanto \& Subianto (2009), edukasi adalah memfasilitasi proses belajar para penerima manfaat penyuluhan yang dilakukan oleh penyuluh, penyuluh memberikan pelajaran kepada petani dengan tujuan sebagai penyebarluasan informasi, pemberi penjelasan, perubah perilaku petani dalam berusahatani. Hal ini menunjukkan bahwa penyuluh pertanian memberikan penyuluhan kepada petani sesuai dengan kebutuhan petani dan memberikan informasi yang dapat meningkatkan pengetahuan petani, serta mengadakan pertemuan rutin dengan kelompok tani. Terdapat beberapa peran penting penyuluh pertanian yaitu peran penyuluh pertanian dalam melaksanakan fasilitasi, melaksanakan konsultasi, melaksanakan supervise/pembinaan, melaksanakan monitoring dan evaluasi. Tim pelaksana pengabdian melakukan pendampingan dan monitoring kegiatan pencatatan usaha tani di Desa Lebuh Lurus Kecamatan Inuman Kabupaten Kuantan Singingi.

\section{KESIMPULAN}

Keunggulan bersaing, inteligen pesaing, hubungan kerja lintas fungsi dan peran penyuluh pertanian sebagai solusi untuk meningkatkan kinerja pemasaran pada UKM perkebunan kelapa sawit di Desa Lebuh Lurus Kecamatan Inuman Kabupaten Kuantan Singingi Provinsi Riau. Bisnis kelapa sawit merupakan salah satu bisnis yang dapat membantu perekonomian negara dan membantu meningkatkan kesejahteraan masyarakat. Partisipasi masyarakat sangat diperlukan terutama untuk menjaga keberlanjutan program dan dalam rangka menumbuhkan kepedulian berbagai pihak terkait di tingkat lokal dalam pemberdayaan masyarakat.

\section{UCAPAN TERIMA KASIH}

Penulis mengucapkan terimakasih kepada Lembaga Penelitian dan Pengabdian kepada Masyarakat (LPPM) Universitas Riau dan Fakultas Ekonomi dan Bisnis (FEB) Universitas Riau.

\section{Daftar Pustaka}

1. Alimuddin, A. (2016). Pengaruh Orientasi Wirausaha Terhadap Keunggulan Bersaing Berkelanjutan Dan Kinerja Pemasaran Usaha Kecil Sector Perdagangan Di Kota Surabaya. Jurnal Manajemen Bisnis, 3(2), 1-10. http://jp.feb.unsoed.ac.id/index.php/sca1/article/viewFile/229/234

2. Anshori, M. Y. (2015). Pengaruh Orientasi Pasar, Intelectual Capital Dan Orientasi Pembelajaran Terhadap Inovasi. Jurnal Manajemen Bisnis, 3(3), 317-329. http://www.irjbs.com/index.php/jurnalirjbs/article/view/76

3. Cravens, David \& Piercy, Nigel. (2006). Marketing Strategic. Nine ${ }^{\text {th }}$ Edition, Singapore: Mc Graw-Hill companies co.

4. Hartanty, I. T. dan Alifah. R. (2013), Peningkatan Kinerja Pemasaran Melalui Optimalisasi Keunggulan Bersaing. Jurnal EKOBIS, 14(2), 72-89.

https://core.ac.uk/download/pdf/236373998.pdf

5. Hasibuan, M. A. M. (2009). Manajemen Tenaga kerja Kelapa Sawit (Elaeis Guineensis Jacq) di kebun Mentawak, PT. Jambi Agro Wijaya, Bakrie Sumatra Plantation, Sorolangun, Jambi. (Skripsi). Institut Pertanian Bogor. 
6. Hutt, Michael D. and Speh, T. W. (2004). Business Marketing Management: A Strategic View of Industrial and Organizational Marketz, Eight Edition, Thomson South-Western, New York.

7. Mardikanto, T. \& Soebianto, P. (2013). Pemberdayaan Masyarakat dalam Perspektif Kebijakan Publik. Bandung: Alfabeta.

8. Parham, D. (2011). Definition, Importance and Determination of Productivity. Workshop for The Public Sector Linkages Program. University of Adelaide. Adelaide

9. Pujawan, L. N dan Mahendrawati, E. R. (2010). Supply Chain Management, Penerbit Guna Widya, Surabaya.

10. Savitri, E. \& Syahza, A. (2019). Effect of Human and Competitive Strategies Against The Financial Performance of Small and Medium Enterprises. International Journal of Scientific \& Technology Research, 8(4), 86-92. https://www.ijstr.org/paper-references.php?ref=IJSTR-0419$\underline{20104}$

11. Syahza, A. (2019). The Potential of Environment Impact as a Result of The Development of Palm Oil Plantation. Management of Environment Quality, 30(5), 1072-1074. https://doi.org/10.1108/MEQ-11-2018-0190

12. Solikhin, A. M, Fauzi, H. K, Purwadaria. (2012). Analysis of Oil Palm Sustainable Replanting Models, A Casc at PT Agrowiyana, Tunggal Ulu, Tanjung Jabang Barat, Jambi. Jurnal Manajemen \& Agribisnis, 9(2), 49-54. https://journal.ipb.ac.id/index.php/jmagr/article/view/5530

13. Muchlis, A. Sumarwan, U, Suharjo, B, Maulana, A. (2012). Key Success Values in Relationship Marketing of Agriculture Products. Jurnal Management \& Agribisnis, 9(1), 59-67. https://journal.ipb.ac.id/index.php/jmagr/article/view/5209

14. Weerawardena, J. (2003). Exploring the role of market learning capability in competitive strategy. European Journal of Marketing, 37(3/4), 407-429. https://doi.org/10.1108/03090560310459023 